\title{
Health sector's flood response plan: A comprehensive review
}

\author{
Ali Mohajervatan ${ }^{\circledR}$, Nahid Tavakoli ${ }^{2^{*}}$, Hamidreza Khankeh ${ }^{3}$, Ahmad Reza Raeisi $^{\circledR}{ }^{\circledR}$ Golrokh Atighechian $^{4^{\circledR}}$ \\ ${ }^{1}$ Department of Health in Disaster and Emergencies, School of Management and Medical Information Sciences, Isfahan University of \\ Medical Sciences, Isfahan, Iran \\ ${ }^{2}$ Health Management and Economics Research Center, Isfahan University of Medical Sciences, Isfahan, Iran \\ ${ }^{3}$ Research Center for Emergency and Disaster Health, University of Social Welfare and Rehabilitation Sciences, Tehran, Iran \\ ${ }^{4}$ Health Management and Economics Research Center, Isfahan University of Medical Sciences, Isfahan, Iran
}

\begin{abstract}
Background: Floods are the most common natural disaster which may have substantial impacts on the human health and life and the environment. In recent years, Iran have faced many floods and it seems that increasing impacts of floods in Iran are attributed to inadequate preparation and no well-established strategies and guidelines for response by health sector and other related response organizations. So, this study was conducted to review the current plans in the world to identify the required elements of the flood emergency response plan to prevent its consequences on the health sector in Iran.

Methods: A comprehensive review was performed through search on electronic data bases, including, Medline, Scopus, ProQuest, and e-journals which were accessible during 2010-2020. The keywords were response plan, flood, requirements, guidelines, and health sector. Data were collected using data extraction form and analyzed through content analysis.

Results: In the initial search, 960 possible sources of flood response were identified. After excluding duplicate papers and the documents that did not contribute to the flood response plan, 64 articles and programs or guidelines that all them has been reviewed, were obtained. The findings were divided into two groups, response prerequisites and response activities.

Conclusion: This review provided a complete view of the flood consequences for the health sector and allows professionals to incorporate facets of the health effect of floods into a flood response plan. The flood response plan was divided into two general categories: Initial and specific, each of which plays an important role in preventing the negative effects of the floods.

Keywords: Flood, Response plan, Health sector, Response prerequisite, Response action

Citation: Mohajervatan A, Tavakoli N, Khankeh H, Raeisi AR, Atighechian G. Health sector's flood response plan: A comprehensive review. Environmental Health Engineering and Management Journal 2021; 8(3): 169-178. doi: 10.34172/EHEM.2020.20.
\end{abstract}

\section{Article History:}

Received: 7 February 2021

Accepted: 4 April 2021

ePublished: 26 July 2021

\section{Introduction}

The phenomenon of climate change is one of the environmental problems stemming from the economic and technological growth of the last two centuries (1). Climate change may increase the probability and intensity of extreme weather, such as extreme precipitation events, which can contribute to more floods in some areas (2). Increased occurrence of severe precipitation events has significant impacts on urban environments as a result of flooding, and floods may have substantial impacts on the human health and life, properties, infrastructure, and the environment (3-7). Floods are naturally caused by an increase in temperature resulting in the heavy runoff, melting of the ice, and thermal expansion of the water, resulting in an increase in sea levels and inundation of coastal areas (8). The impacts on the human health and the environment arising from flooding vary from location to location, depending on the magnitude of the event, susceptibility, and exposure of the impacted population (9). Floods are the most common natural disaster in Iran. In recent years, different regions of Iran have faced many floods due to climate change and rain (10). In 2019, heavy rains and floods affected more than 2000 cities and 31 provinces in Iran. It is estimated that 10 million people have been affected, 78 people lose their lives, and more than 1136 injured (11). Iran is involved in many complex political, economic, and social circumstances, so such increasing impacts are attributed to inadequate preparation and inefficient use of modern strategies and planning. On the other hand, it is obvious that the current traditional planning can no longer overcome every complicated issue and change the environment in these events (12). Adaptation and dealing with this risk involves a mixture of policies or strategies that are used in various 
locations and magnitudes of floods (13). Also, increasing readiness for effective response is a significant topic that is strongly underlined by the Sendai framework (14). Iran is one of the few countries to have developed a national health disaster response plan with all-hazards approach (15). But planning for a particular event is important and can be very successful in the effectiveness of disaster management (12). Based on the lesson learned from Iran's flood response in 2019, the National Health System Response Plan does not have the potential to provide a cohesive and proper response, so that despite the efforts made, much of the flood needs have not been responded. While floods are the most common natural disasters in Iran, few reviews cover the health sector's response problems that arise afterward. So, for preparing the national response plan to flood, this study was conducted to survey the current plans in the world to identify the required elements of the flood disaster response plan to prevent its consequences on health sector in Iran.

\section{Materials and Methods}

A comprehensive review was performed to collect data, identify the criteria and the elements required for the flood response plan in the health sector. Context and subject matter of this research, was accomplished by a literature review to determine the dimensions and criteria of the health system's flood response plan. For this purpose, all studies on the effects of floods on health as well as all studies on the flood response plan in the health system, from 2010 to 2020 were searched by keywords in Medline. A combination of terms defining: Flood and health, health effects, response plan, flood impact, flood response plan, disaster plan in PubMed, Springer, Emerald, ProQuest, ScienceDirect, Google Scholar, SID, and organization web site of FEMA, OCHA, JICA, NIDM, the United Nations, and the WHO, were scanned for further references. The abstracts of articles identified in this search strategy were screened. References from each relevant article were scanned for further relevant articles. Non-published papers, reports, thesis, and unpublished literature plan are among the items that are enrolled in the studies called gray literature. These literatures played an important role in the rapid and timely transmission of in-depth, new, scientific, and technical information. It was tried to balance the biases that may have been in the published material by searching the gray literature. These texts include reports related to flood response plans, national and international guides and programs among countries. In this study, the content was searched through two strategies. In the first strategy, keywords related to the purpose of the research in both English and Persian databases were searched. For this reason, studies, research papers and reports in the last 10 years, experiences and challenges in various countries in response to flood risk were studied. In the second strategy, the following methods (Table 1) were used to identify gray studies.

To assess the quality of printed studies, each study was evaluated by at least two people. Studies in which the infrastructures, strategies, patterns, consequences, experiences, and challenges of different countries in response to flood risk were addressed, were included in the study and other studies were excluded from the study. Resources that have obtained the minimum necessary credentials were further examined to collect data and extract information related to the purpose of the research, and the information required for analysis was extracted.

Data were collected using data extraction forms. These forms are used to maintain integrity, reduce bias, and increase the validity and reliability of the comprehensive review reference.

The first author examined different articles in terms of characteristics, methods, and results. The main characteristics of floods, the affected area, and the health consequences of floods from different extraction articles were entered in data extraction forms. Data were analyzed using the content analysis method based on the dimensions of the flood response plan.

\section{Results}

In the initial search, 960 possible sources of flood response were identified. After excluding duplicates, papers, documents and programs that did not contribute to the response process and the effects of the flood risk, 64 articles and programs or guides were obtained. The full text of all 64 papers, plans and reports and recommendations was reviewed. The findings were listed in two groups: Response prerequisites and response activity.

Response prerequisites

In this study, factors that influence the response to the floods were identified. These elements were described as the prerequisites for the implementation of a flood response plan. In this comprehensive review, the prerequisites include: Nature of hazard, population, time, and flood consequences.

Nature of hazard: The factors related to the nature of the hazard in this comprehensive review include depth of flood (16), distance to the river, scope and duration (17), types of floods (17-20), and causes of floods (21) (Table 2).

Population: The findings of this research showed that in addition to the type and manner of the event, the

Table 1. Stages of gray studies extraction

\begin{tabular}{lll}
\hline First Step & Second Step & Third Step \\
\hline $\begin{array}{l}\text { Manually search for gray texts from } \\
\text { primary sources (related organizations) }\end{array}$ & $\begin{array}{l}\text { Use keywords to search for web-based } \\
\text { gray texts }\end{array}$ & Refine searches by identifying key institutions \\
\hline
\end{tabular}


characteristics of the flood plain population $(19,20,23)$, including population density, characteristics such as endemic diseases, age, gender, level of education, income, household size, diverse sources of income, housing ingredients, past flood experience and social networks (24), also, influence the impacts of the floods.

Time: It is one of the most effective variables in the form of response to post-flood conditions (25-28). In this comprehensive review, the effects of floods on health were recorded at various time intervals, short or immediate and long-term effects $(29,30)$ or described in terms of immediate, medium, and long-term (21). However, no clear distinction was found between these terms. obviously, these courses overlap in several respects. However, this classification is useful for planning and implementation of management strategies.

Flood consequences: The findings of this research show that floods have a different influence on the health system (mortality, illness, and loss of health infrastructure). It seems that paying attention to these consequences may be the foundation for a thorough answer. These effects were categorized into two categories: Indirect (Table 3) and direct (Table 4) impacts.

\section{Response activity}

The response phase begins immediately after a disaster and includes both immediate response (relief) and mediumterm response. When a disaster has arisen, the priority is to offer effective relief to help those affected recover from the acute impact of the disaster. Such relief work includes providing food, clothing, shelter, and medical care to victims (57). The results of this research showed that two kinds of activity were taken in response to the flood, which was categorized into the initial and specific measures.

\section{Initial Action}

The initial action taken in response to a disaster must be taken quickly and early to be most successful. It is necessary to respond as quickly as possible, even though we do not have a clear understanding of the epidemiology of its consequences until adequate data emerges regarding the effects of an accident. These acts can reduce and control the risk of consequences. They are more important because the potential consequences of implementing the initial measures are very small (58). The initial actions recommended below (Table 5) should be implemented at the appropriate level to respond to the disaster, then, the need for further actions is estimated and unnecessary activities are avoided. The results of a comprehensive review of these activities are given in Table 5 .

\section{Specific Action}

The phrase "specific action" was used to include all operations of medical and public health services impacted by the floods. These actions including treatment of existing casualties and prevention and treatment of future casualties are categorized in Table 6 .

\section{Discussion}

In the present study, the factors influencing the flood response with a comprehensive study in the health sector were studied. Finally, 39 key studies and 25 gray documentaries were identified as the prerequisites for response and response activities to floods. Flood risk impacts and plans identified in this review can potentially be used to help the decisions of disaster management. It was found that multiple interdependent systems can be impacted by flood disasters (Tables 3 and 4 ), so there is

Table 2. Causes of floods $(21,22)$

\begin{tabular}{|c|c|c|c|}
\hline Category of Causes & Underlying Causes & Comments and Examples & Type of Flood \\
\hline \multirow[b]{2}{*}{ Precipitation } & Rain & The impact is dependent on the size and rapidity of the rain & Flash flooding \\
\hline & Snow & $\begin{array}{l}\text { Immediate impact from the snow and its impact and delayed } \\
\text { impact from melting of snow and ice }\end{array}$ & River (fluvial) flooding \\
\hline \multirow{4}{*}{ Rising water level } & Sea water & $\begin{array}{l}\text { Sudden rises associate with tidal waves, tsunami, and storm } \\
\text { surge }\end{array}$ & \multirow[t]{2}{*}{ Coastal flooding } \\
\hline & & Long terms rise due to global warming & \\
\hline & \multirow[t]{2}{*}{ Fresh water } & $\begin{array}{l}\text { Rising levels associated with planned or unplanned damming } \\
\text { of waterways }\end{array}$ & \multirow{2}{*}{$\begin{array}{l}\text { River (fluvial) flooding/ } \\
\text { Groundwater flooding }\end{array}$} \\
\hline & & Rising subterranean water & \\
\hline \multirow{3}{*}{ Structural failure } & Failure of the dam & $\begin{array}{l}\text { The collapse of water retaining structures with a sudden } \\
\text { release of stored water }\end{array}$ & \multirow{3}{*}{ Groundwater flooding } \\
\hline & $\begin{array}{l}\text { Relocation of the } \\
\text { stored water }\end{array}$ & Landslide into a reservoir displacing large quantities of water & \\
\hline & $\begin{array}{l}\text { Breaching of sea } \\
\text { defenses }\end{array}$ & Breaching of dykes in New Orleans & \\
\hline \multirow{2}{*}{$\begin{array}{l}\text { Reduced natural } \\
\text { drainage }\end{array}$} & $\begin{array}{l}\text { Prevention of natural } \\
\text { absorption }\end{array}$ & $\begin{array}{l}\text { Development of wetlands, which reduces the absorption of } \\
\text { rainfall }\end{array}$ & \multirow{2}{*}{ Groundwater flooding } \\
\hline & Blocked drainage & $\begin{array}{l}\text { Poor planning of water drainage infrastructure or through } \\
\text { blocked drainage due to debris or trash }\end{array}$ & \\
\hline
\end{tabular}


Table 3. Indirect impact on health

\begin{tabular}{ll}
\hline Category & Sub-category \\
\hline Social & $\begin{array}{l}\text { Migration due to flood }(31,32) / \text { displacement }(33) / \text { negative health effects linked with overcrowding/livelihoods } \\
(34,35) / \text { vulnerable groups }(36) / \text { communication networks }(18,34,37)\end{array}$ \\
\hline Economic & Disruption of food supplies/property (34)/livestock \\
\hline Environment & $\begin{array}{l}\text { Destruction of houses }(34,38) / \text { remote and hard to reach areas }(37) / \text { disruption infrastructure }(34,38,39) / \text { dysfunction, } \\
\text { service interruption/power and energy }(34)\end{array}$ \\
\hline Industrial & $\begin{array}{l}\text { Exposure to mold and industrial and household chemicals }(17,35,40) / \text { industrial center }(34,40) / \text { Accompanying } \\
\text { events }(38)\end{array}$ \\
\hline Agriculture & Toxic agriculture/healthcare of animals (37)/fisheries/damage to crops (35)/Livestock (34) \\
\hline
\end{tabular}

Table 4. Direct impacts of flood on health

\begin{tabular}{|c|c|c|}
\hline Category & Consequence & Example \\
\hline \multirow{8}{*}{$\begin{array}{l}\text { Disease } \\
\text { or acute } \\
\text { emergency }\end{array}$} & $\begin{array}{l}\text { Injury (injuries from contact } \\
\text { with debris and submerged } \\
\text { objects in flood water; falling } \\
\text { into hidden manholes; trying to } \\
\text { move possessions during floods; } \\
\text { building collapse and damage; and } \\
\text { electrocution (35)) }\end{array}$ & $\begin{array}{l}\text { Rash }(19,35,39,41-43) \text { /electrocution }(17,19,35,40,41) / \text { fractures }(19) / \text { falls }(31,40) / \text { cut } \\
(19,31,40,41) / \text { lacerations }(19,29,31) / \text { car crash }(19,31) / \text { chemical injury }(41) / \text { disabilities } \\
(19,37,44) \text { /traffic injuries }(45) / \text { sprains }(19) / \text { injury }(19,29,31,34,41-43,45) / \text { carbon monoxide } \\
\text { poisoning }(19,29,40-43) / \text { burns }(19)\end{array}$ \\
\hline & Drowning & Near drowning (19)/drowning $(17,19,29,31,35,40)$ \\
\hline & Deaths & Deaths $(19,31,34,35,45)$ \\
\hline & Uncommunicable disease & $\begin{array}{l}\text { Infant pneumonia/aspiration pneumonitis }(29) / \text { pneumonia }(34) / \text { cardiac events }(35,41) / \text { parasitic } \\
\text { disease }(43) / \text { high blood pressure }(19) / \text { headaches }(19) / \text { rheumatism }(19) / \text { chronic conditions }(40) / \\
\text { long-term treatment for chronic infectious disease }(37) / \text { heart attack }(17,19,35) / \text { infant meningitis } \\
(34) / \text { mosquito-borne illnesses }(29) / \text { malaria }(34,39) / \text { snake bite }(35,39) / \text { vomiting }(41) / \text { common cold } \\
(39) / \text { noxious inhalation }(41) / \text { worsening asthma/hypothermia }(19,29,31) / \text { earache }(19) / \text { malnutrition } \\
(25,34) / \text { maternal hemorrhage }(34) / \text { maternal and neonatal sepsis }(34) / \text { worsening asthma (19)/ } \\
\text { increase in medication usage }(46) / \text { conjunctivitis (47) }\end{array}$ \\
\hline & Communicable disease (25) & $\begin{array}{l}\text { Poliomyelitis (34)/typhoid fever (19)/gastrointestinal illness }(19,29,42,43,48) / \text { hemorrhagic fever } \\
\text { (CCHF) (34)/leptospirosis }(29,42,43) / \text { typhoid fever/schistosomiasis/vector-rodent-borne diseases } \\
(35,42,43) \text { /water-borne diseases }(17) / \text { leishmaniosis }(29,34) / \text { measles/hepatitis B and C/E }(17,29,34) / \\
\text { tuberculosis }(34) / \text { diarrhea }(19,34,35,37,39,41-43,47,49) / \text { febrile illnesses }(37)\end{array}$ \\
\hline & Psychological distress & $\begin{array}{l}\text { Digestive problems/conjunctivitis/substance use }(41) / \text { anxiety }(46) / \text { stress }(35,50) / \text { post-traumatic stress } \\
\text { disorder (PTSD) }(46,51,52) / \text { psychological distress }(17,19,25,31,37,46) / \text { depression }(17,46,51,52) / \\
\text { suicide }(46) / \text { psychological well-being }(29,51-53) / \text { psychosocial distress }(35,41,52,53) / \text { increase in } \\
\text { tobacco, alcohol, and other substance }(46) / \text { development of acute mental health symptoms }(37,40) / \\
\text { violent behavior (41) }\end{array}$ \\
\hline & Infections & $\begin{array}{l}\text { Fungal infections (47)/skin infections (35)/eye infections (35)/dermatitis (47)/kidney infection (19)/ } \\
\text { cutaneous infection (29)/infection/viral infection (39)/respiratory infection }(29,34,41,42)\end{array}$ \\
\hline & Violent & Sexual assault $(25) /$ violent behavior $(41,45)$ \\
\hline \multirow{4}{*}{$\begin{array}{l}\text { Impact on } \\
\text { health facility }\end{array}$} & $\begin{array}{l}\text { Primary health care system } \\
\text { dysfunction }(17,31,35,39,47,54)\end{array}$ & $\begin{array}{l}\text { Loss of paper-based medical records and inaccessibility of electronic medical records and } \\
\text { laboratory information systems (29)/hospital functions affected by water supply issues, including } \\
\text { the recovery of sterile processing for surgical equipment's ( } 29) \text { /hospital disruptions }(54) / \text { loss of } \\
\text { access to essential care; or loss of access to and failure to obtain continuing health care (35), } \\
\text { negative health effects linked with overcrowding (35), inadequacy of professional staff (47) }\end{array}$ \\
\hline & An increase in medication usage & $\begin{array}{l}\text { Increases in emergency department visits (29), long-term treatment for chronic infectious diseases } \\
\text { such as tuberculosis and HIV/AIDS }(31,37)\end{array}$ \\
\hline & $\begin{array}{l}\text { Contamination of floodwaters, and } \\
\text { damage to water and sanitation } \\
\text { infrastructure }(17,29,34)\end{array}$ & $\begin{array}{l}\text { Water shortages and contamination due to loss of water treatment works and sewage treatment } \\
\text { plants (35) }\end{array}$ \\
\hline & Birth outcomes & $\begin{array}{l}\text { By affecting the physical and mental health of pregnant mothers and their ability to access health } \\
\text { services, floods may affect the health of newborns (55) and negative health outcomes in children, } \\
\text { including behavioral problems and psychiatric disorders (56) }\end{array}$ \\
\hline
\end{tabular}


Table 5. Initial actions

\begin{tabular}{|c|c|}
\hline Type of action & Example \\
\hline Early warning & $\begin{array}{l}\text { Ownership and audience/declaration/criteria/warning }(15,29,42,59-63) / \text { evacuation of population and } \\
\text { facility }(15,18,32,38)\end{array}$ \\
\hline Information management & $\begin{array}{l}\text { Data collection }(25,35,45,63) / \text { initial damage assessment }(27,64) / \text { rapid needs assessment }(64-67) / \\
\text { assessment }(25,34,38,62,63) \text { /public information }(27,37,39,63,65) / \text { performance monitoring and evaluation } \\
(63)\end{array}$ \\
\hline Management/command & Incident command system (ICS) or incident management system $(26,27,61,63,64,68-70)$ \\
\hline Coordination & International coordination $(63,69,71) /$ coordination $(26,27,37,63,68-70) /$ private-sector coordination $(71-73)$ \\
\hline \multirow{2}{*}{ Incident action plan } & Operational plan to protect public health and workers' safety and health (71) \\
\hline & Plan activation-thresholds and triggers (63) \\
\hline Safety/security & Household action and safety/security/relief camps (37) \\
\hline \multirow{5}{*}{ Logistics } & Volunteer management $(35,37,71,73)$ \\
\hline & Displaced population health protection/relief shelters and temporary health facilities $(64,70,71)$ \\
\hline & Logistics management (70) \\
\hline & Financial management (71) \\
\hline & Transportation of patients (71) \\
\hline
\end{tabular}

a need for coordination $(26,27,37,63,68-70)$ between decision makers, first responders, and the community (18). It was also found that flood health impacts are well known (29) but it needs more understanding to incorporate them into the specific response program. The findings of this study showed that direct and indirect consequences of floods depend on the context in which the floods occur. Factors such as the type of flood, population density, time, and endemic diseases of the region affect the vulnerability and exposure of people to different health outcomes and their long-term medical needs $(17-20,23)$. For example, in a flash flood in Nepal, the risk of fatality increased among people living in houses constructed of thatch as opposed to brick (75). The findings of the study of Zahran et al showed that the risk of fatality increases with the level of precipitation on the day of the flood, flood duration, property damage caused by the flood, population density, and social vulnerability (76). Also, flash floods, as opposed to slow rise floods or riverine floods, can cause considerable damages to lives, communities, and property as they can present suddenly and without warnings (77). The response seems to be directly related to the kind of event, and even the time after it happens $(21,78)$. The next steps can be predicted by learning them and provide an efficient answer. Other sources confirm that the response is also affected by the following characteristics, including the type of disaster, the severity and extent of disaster, the ability to take pre-impact action, the capability for sustained operations, and identification of likely response requirements (79). The findings of this comprehensive review showed that floods have multiple effects on the health sector. Knowing any of these consequences can be a good basis for a response plan for future events. In the present research, the health effects of floods can be categorized into short-term and long-term effects $(21,25-$
$28,30)$. The health consequences of floods are caused by contact with flood water and disruption of the health system $(17,31,35,39,47,54)$. Among other factors, these factors reduce people's access to health care, and thus, increase illness and death (80). Another important thing is that the availability of health services is an important aspect of the proper functioning primary healthcare system and the requirements of appropriate response $(81,82)$. The results of the study of Ahmad et al showed that communities that had more health facilities damaged by the flood were more vulnerable (77). The health response to a disaster should be driven by the identified and expected needs of the affected population. It should be prepared for needs created by direct results (Table 4) and indirect consequences (Table 3 ) of the incident. The results of examined studies also indicated that response plans should use the best available data to consider the acute, short-term, and long-term results of health following an event (43). The findings of the present study showed the outbreaks of gastrointestinal illnesses, leptospirosis, mosquito bite diseases, and chemical toxicity occurred after flooding $(29,42,43,83)$. Public health interventions (direct and indirect impact) can be targeted to these outcomes to prevent negative consequences. Increased treatment for poisoning and diseases found after floods is likely to result from extreme flooding of water and associated material flooding. Increased demand for treatment should during be accounted for during flood responses. This observation is supported by other published research and programs $(27,62)$. The findings of this research have shown that the occurrence of direct and indirect effects on flooding is well known, but no concrete plans has been identified to address these needs. A study on the conditions for an effective response to flooding from the viewpoint of the operational teams participating in the relief operations 
Table 6. Specific actions

\begin{tabular}{|c|c|}
\hline Specific Function & Sub-category \\
\hline \multirow{7}{*}{ Continuity of health care } & Child health (62) \\
\hline & Immunization programmers $(62) /$ vaccination during flood events $(47,35)$ \\
\hline & Sexual and reproductive health (62) \\
\hline & Mental health $(46,62,64)$ \\
\hline & Non-communicable diseases $(62,64)$ \\
\hline & Continuity of the hospital supply and delivery chain $(35,62)$ \\
\hline & Sanitation and hygiene in healthcare facilities during and after flood events $(35,62,64)$ \\
\hline \multirow{10}{*}{ Emergency care } & Rescue $(25,73)$ \\
\hline & First-aid at site (25) \\
\hline & General clinical services and essential trauma care (70) \\
\hline & Emergency maternal and neonatal care \\
\hline & Surge capacity $(17,25,35)$ \\
\hline & Mass-casualty triage protocol (35) \\
\hline & Availability of essential services (35) \\
\hline & Effective management of human resources (35) \\
\hline & Health of relief workers (37) \\
\hline & Temporary health facilities (64) \\
\hline \multirow{17}{*}{ Public health services } & Health education and promotion $(15,37,62,70,74)$ \\
\hline & Control of communicable disease outbreaks $(25,35,62,70)$ \\
\hline & Disease surveillance $(25,35,37,62,70)$ \\
\hline & Management of dead and missing people (62) \\
\hline & Environmental health $(62,70)$ \\
\hline & Water, sanitation, and hygiene $(35,62,64,70,74)$ \\
\hline & Vector control $(35,62,70)$ \\
\hline & Waste management/Moulid clean-up and removal (62) \\
\hline & Chemical hazards and toxins management $(35,62)$ \\
\hline & Radiological hazard (62) \\
\hline & Management of chronic disease $(29,37)$ \\
\hline & Transportation of casualties to designated hospitals $(25,70)$ \\
\hline & Sanitation and hygiene in healthcare facilities during and after flood events $(35,70)$ \\
\hline & Hospital care $(35,70)$ \\
\hline & Displaced population health protection (70) \\
\hline & Snakebite (35) \\
\hline & Rodent-borne diseases (35) \\
\hline Food security, safety, and nutrition & Nutrition $(35,37,62,65,70,74)$ \\
\hline \multirow{3}{*}{ Health security } & Societal measures (e.g. quarantine, school closures, cancellation of mass gatherings) (62) \\
\hline & Prevention and control at points of entry (62) \\
\hline & Operational plan to protect public health and workers' safety and health (71) \\
\hline
\end{tabular}


of the health sector may be a valuable addition to these findings. The results of the present study showed that most of the response activities in the flood event (Tables 5 and 6) are related to the needs created by its occurrence. These needs are listed in Tables 3 and 4 . The available evidence also confirms these findings $(3,59,74)$. These activities were divided into initial and special actions. Initial activities (Table 5) identify the need for special activities and prevent the wastage of resources. For example, rapid needs assessment refers to a collection of epidemiological, scientific, and anthropological tools that provide accurate and population-based knowledge to decision-makers in a simple format that can be used in floods to provide rapid and low cost decision, which is consistent with the results of other studies (84). Various components are required for flood response plan, some of which can be extracted from previous and recorded flood information. This knowledge makes the necessary projections for the various aspects of the application. On the other hand, in a comprehensive response, interventions since the beginning of the event begins when we do not have sufficient details of the incident and the response continues until we have the necessary resources.

\section{Conclusion}

This review provides a complete view of the health sector's flood consequences and allows professionals to incorporate facets of the health effect of flooding into a flooding response plan. Using these data, the flood response plan was divided into two general categories: Initial and specific, each of which plays an important role in preventing the negative effects of the floods.

\section{Acknowledgments}

This article is extracted from $\mathrm{PhD}$ dissertation. All authors would like to express their gratitude to Isfahan University of Medical Sciences for supporting this study (Research ID: 399504).

\section{Ethical issues}

This article was approved by the Ethics Committee of Isfahan University of Medical Sciences (Ethical code: https:/ethics. research.ac.ir/IR.MUI.RESEARCH.REC.1399.498).

\section{Competing interests}

The authors declare that they have no conflict of interests.

\section{Authors' contributions}

All authors were involved in the study design, data collection and analysis, and writing - original draft, and writing - review and editing manuscript. The final version of the manuscript was reviewed and confirmed by all authors.

\section{References}

1. Salimi Turkamani H. From legal responsibility of states to their ethical responsibility in the context of climate change. Journal of Legal Studies 2018; 10(2): 105-33. doi: 10.22099/ jls.2018.27734.2702. [In Persian].
2. Quintero F, Mantilla R, Anderson C, Claman D, Krajewski W. Assessment of changes in flood frequency due to the effects of climate change: Implications for engineering design. Hydrology 2018; 5(1):19. doi: 10.3390/hydrology5010019.

3. Mahmood MI, Elagib NA, Horn F, Saad SA. Lessons learned from Khartoum flash flood impacts: An integrated assessment. Sci Total Environ 2017; 601: 1031-45. doi: 10.1016/j.scitotenv.2017.05.260.

4. Changnon SA, Pielke Jr RA, Changnon D, Sylves RT, Pulwarty R. Human factors explain the increased losses from weather and climate extremes. Bulletin of the American Meteorological Society 2000; 81(3): 437-42. doi:10.1175/1520-0477(2000)081<0437:hfetil>2.3.co;2.

5. George P. Health Impacts of Floods. Cambridge: Cambridge University Press; 2011.

6. Chau VN, Holland J, Cassells S, Tuohy M. Using GIS to map impacts upon agriculture from extreme floods in Vietnam. Applied Geography 2013; 41: 65-74. doi:10.1016/j. apgeog.2013.03.014.

7. Agbola BS, Ajayi O, Taiwo OJ, Wahab BW. The August 2011 flood in Ibadan, Nigeria: Anthropogenic causes and consequences. Int J of Disaster Risk Science 2012; 3(4): 207 17. doi:10.1007/s13753-012-0021-3.

8. Etuonovbe AK. The devastating effect of flooding in Nigeria. [cited 2020 Oct 15] Available from: https://www. oicrforg/-/the-devastating-effect-of-flooding-in-nigeria.

9. Environmental Protection Agency. Climate Change Indicators in The United States. 4th ed. USA: EPA; 2016.

10. Ghanbari V, Maddah SS, Khankeh HR, Karimloo M, Ardalan A. The effect of a disaster nursing education program on nurses' preparedness for responding to probable natural disasters. IJ of Nursing 2011; 24(73): 7280. [In Persian].

11. Yadollahie M. The flood in Iran: a consequence of the global warming? Int J Occup Environ Med 2019; 10(2): 54-6. doi: 10.15171/ijoem.2019.1681.

12. Nojavan M, Salehi E, Omidvar B, Faryadi S. The study of theoretical approach of natural disaster management in iran using the concept of meta-analysis. J Environmental Science and Technology 2016; (In Press): 1-15. [In Persian].

13. Hosseini SH, Khalegh MR, Jami H, Baygi S. Comparison of hybrid regression and multivariate regression in the regional flood frequency analysis: A case study in Khorasan Razavi province. Environmental Health Engineering and Management Journal 2018; 5(2): 93-100.

14. Aitsi-Selmi A, Murray V. The Sendai framework: disaster risk reduction through a health lens. Bull World Health Organ 2015; 93(6): 362. doi: 10.2471/BLT.15.157362.

15. Cvetković VM, Roder G, Öcal A, Tarolli P, Dragićević S. The role of gender in preparedness and response behaviors towards flood risk in Serbia. Int J Environ Res Public Health 2018; 15(12): 2761. doi: 10.3390/ijerph15122761.

16. Department for Environment, Food \& Rural Affairs, Environment Agency, Public Health England. The National Flood Emergency Framework for England. [2020 Mar 20] Available from: https://www.gov.uk/government/ publications/the-national-flood-emergency-frameworkfor-england.

17. Veenema TG, Thornton CP, Lavin RP, Bender AK, Seal S, Corley A. Climate change-related water disasters' impact 
on population health. J Nurs Scholarsh 2017; 49(6): 625-34. doi: 10.1111/jnu.12328.

18. Oddo PC, Bolten JD. The value of near real-time earth observations for improved flood disaster response. Frontiers in Environmental Science 2019; 7: 127. doi: 10.3389/fenvs.2019.00127.

19. Lowe D, Ebi KL, Forsberg B. Factors increasing vulnerability to health effects before, during and after floods. Int J Environ Res Public Health 2013; 10(12): 7015-67. doi: 10.3390/ijerph10127015.

20. Shi Y, Zhai G, Zhou S, Lu Y, Chen W, Deng J. How can cities respond to flood disaster risks under multiscenario simulation? A case study of Xiamen, China. Int J Environ Res Public Health 2019; 16(4): 618. doi: 10.3390/ ijerph16040618.

21. Du W, Fitz Gerald GJ, Clark M, Hou XY. Health impacts of floods. Prehospital and Disaster Medicine 2010; 25(3): 26572. doi: $10.1017 / \mathrm{s} 1049023 \times 00008141$.

22. United States Environmental Protection Agency. Underground Storage Tank Flood Guide. [cited 2020 Oct 12] Available from: https://www.epa.gov/sites/production/ files/2014-03/documents/ustfloodguide.pdf.

23. Qiang Y. Disparities of population exposed to flood hazards in the United States. J Environ Manage 2019; 232: 295-304. doi: 10.1016/j.jenvman.2018.11.039.

24. Shah AA, Ye J, Shaw R, Ullah R, Ali M. Factors affecting flood-induced household vulnerability and health risks in Pakistan: The case of Khyber Pakhtunkhwa (KP) Province. In J Disaster Risk Reduction 2020; 42: 101341. doi: 10.1016/j.ijdrr.2019.101341.

25. Emergency Medical Services Division Department of Medical Services Ministry of Health Royal Government of Bhutan Thimphu. Health Emergency and Disaster Contingency Plan. [cited 2020 Oct 12] Available from: http://www.moh.gov.bt/wp-content/uploads/mohfiles/2014/11/Health-Emergency-Disaster-ContingnecyPlan-1st-Edition-Final.pdf.

26. Samsey KM. Medical and public health considerations in US national disaster planning--Thel" All-Hazards।" approach [dissertation]. Texas: University of Texas Medical Branch; 2010.

27. Dizaji RA, Ardalan A, Fatemi F. Response functions in disasters: Iran flash flood 2016. Disaster Med Public Health Prep 2019; 13(5-6):842-844.| doi: 10.1017/dmp.2018.94.

28. Government of the People's Republic of Bangladesh Ministry of Disaster Management and Relief. National plan for disaster management (2016-2020). [cited 2020 Nov 14] Available from: https://modmr.portal. gov.bd/sites/default/files/files/modmr.portal.gov.bd/ policies/0a654dce_9456_46ad_b5c4_15ddfd8c4c0d/ NPDM(2016-2020)\%20-Final.pdf.

29. Paterson DL, Wright H, Harris PN. Health risks of flood disasters. Clin Infect Dis 2018; 67(9): 1450-4. doi: 10.1093/ cid/ciy227.

30. Alderman K, Turner LR, Tong S. Floods and human health: a systematic review. Environ Int 2012; 47: 37-47. doi: 10.1016/j.envint.2012.06.003.

31. Bich TH, Quang LN, Thanh Ha LT, Duc Hanh TT, GuhaSapir D. Impacts of flood on health: epidemiologic evidence from Hanoi, Vietnam. Global Health Action 2011; 4(1):
6356. doi: 10.3402/gha.v4i0.6356.

32. Amadi L, Mac Ogonor CU. (2015). Climate change, environmental security and displacement in Nigeria: Experience from the Niger Delta Flood Disaster, 2012. Afr J Environ Sci Tech 2015; 9(1):53-64. doi.org/10.5897/ AJEST2014.1749.

33. Mort M, Walker M, Williams AL, Bingley A. Displacement: critical insights from flood-affected children. Health \& Place 2018; 52: 148-54. doi: 10.1016/j.healthplace.2018.05.006.

34. Shabir O. A summary case report on the health impacts and responsetothePakistanfloods of 2010.PLoSCurr2013;5. doi: 10.1371/currents.dis.cc7bd532ce252c1b740c39a2a827993f.

35. World Health Organization. Floods and Health: Fact Sheets for Health Professionals. Denmark: WHO Regional office for Europe; 2014.

36. Boonyaratkalin P, Partiprajak S, Piaseu N. Flood preparedness literacy and behaviors in community dwelling older adults. Disaster Medicine and Public Health Preparedness 2020; 1-6. doi: 10.1017/dmp.2020.27.

37. Gaitonde R, Gopichandran V. The Chennai floods of 2015 and the health system response. Indian J Med Ethics 2016; 1(2): 71-5. doi: 10.20529/ijme.2016.021.

38. Babaei J, Banay Jidi M, Moradian M, Arzanloo M, Hajizadah A. A case study of the health system response operation to flood in Chaldoran Township on July 2011. J Rescue and Relief 2012; 4(1): 54-61. [In Persian].

39. Phalkey R, Dash SR, Mukhopadhyay A, Runge-Ranzinger S, Marx M. Prepared to react? Assessing the functional capacity of the primary health care system in rural Orissa, India to respond to the devastating flood of September 2008. Glob Health Action 2012; 5. doi: 10.3402/gha.v5i0.10964.

40. CDC 2017 Hurricane Incident Management System Team. Hurricane Season public health preparedness, response, and recovery guidance for health care providers, response and recovery workers, and affected communities-CDC, 2017. Morbidity and Mortality Weekly Report 2017; 66(37):99598. doi: 10.15585/mmwr.mm6637elexternal icon.

41. Sahni V, Scott AN, Beliveau M, Varughese M, Dover DC, Talbot J. Public health surveillance response following the southern Alberta floods, 2013. Can J Public Health 2016; 107(2): e142-8. doi: 10.17269/cjph.107.5188.

42. McMartin DW, Sammel AJ, Arbuthnott K. Community response and engagement during extreme water events in Saskatchewan, Canada and Queensland, Australia. Environ Manage 2018; 61(1): 34-45. doi: 10.1007/s00267-0170944-y.

43. Saulnier DD, Ribacke KB, von Schreeb J. No calm after the storm: a systematic review of human health following flood and storm disasters. Prehosp Disaster Med 2017; 32(5): 568-79. doi: 10.1017/S1049023X17006574.

44. McDermott S, Martin K, Gardner JD. Disaster response for people with disability. Disability and Health Journal 2016; 9(2): 183-5. doi: 10.1016/j.dhjo.2015.12.005.

45. Prinsloo M. Estimating injury mortality in South Africa and identifying urban-rural differences .[dissertation]. South Africa: University of Cape Town; 2019.

46. Fernandez A, Black J, Jones M, Wilson L, SalvadorCarulla L, Astell-Burt T, et al. Flooding and mental health: a systematic mapping review. PloS One 2015; 10(4): e0119929. doi: 10.1371/journal.pone.0119929. 
47. Van Minh H, Anh TT, Rocklöv J, Giang KB, Trang LQ, Sahlen K-G, et al. Primary healthcare system capacities for responding to storm and flood-related health problems: a case study from a rural district in central Vietnam. Glob Health Action 2014; 7(1): 23007. doi: 10.3402/gha.v7.23007.

48. Crespo RD, Wu J, Myer M, Yee S, Fulford R. Flood protection ecosystem services in the coast of Puerto Rico: Associations between extreme weather, flood hazard mitigation and gastrointestinal illness. Sci Total Environ 2019; 676: 343-55. doi: 10.1016/j.scitotenv.2019.04.287.

49. Zhang N, Song D, Zhang J, Liao W, Miao K, Zhong S, et al. The impact of the 2016 flood event in Anhui Province, China on infectious diarrhea disease: An interrupted timeseries study. Environ Int 2019; 127: 801-9. doi: 10.1016/j. envint.2019.03.063.

50. Roy ED, White JR, Smith EA, Bargu S, Li C. Estuarine ecosystem response to three large-scale Mississippi River flood diversion events. Science of The Total Environment 2013; 458: 374-87. doi: 10.1016/j.scitotenv.2013.04.046.

51. Lieberman-Cribbin W, Liu B, Schneider S, Schwartz R, Taioli E. Self-reported and FEMA flood exposure assessment after Hurricane Sandy: association with mental health outcomes. PLoS One 2017; 12(1): e0170965. doi: 10.1371/journal.pone.0170965.

52. French CE, Waite TD, Armstrong B, Rubin GJ, English National Study of Flooding and Health Study Group, Beck $\mathrm{CR}$, et al. Impact of repeat flooding on mental health and health-related quality of life: a cross-sectional analysis of the English National Study of Flooding and Health. BMJ Open 2019; 9(11): e031562. doi: 10.1136/bmjopen-2019-031562.

53. Woodhall-Melnik J, Grogan C. Perceptions of mental health and wellbeing following residential displacement and damage from the 2018 St. John River Flood. Int J Environ Res Public Health 2019; 16(21): 4174. doi: 10.3390/ ijerph16214174.

54. Rattanakanlaya K, Sukonthasarn A, Wangsrikhun S, Chanprasit C. A survey of flood disaster preparedness among hospitals in the central region of Thailand. Australas Emerg Nurs J 2016; 19(4): 191-7. doi: 10.1016/j. aenj.2016.07.003.

55. Tong VT, Zotti ME, Hsia J. Impact of the Red River catastrophic flood on women giving birth in North Dakota, 1994-2000. Matern Child Health J 2011; 15(3): 281-8. doi: 10.1007/s10995-010-0576-9.

56. Kinney DK, Miller AM, Crowley DJ, Huang E, Gerber E. Autism prevalence following prenatal exposure to hurricanes and tropical storms in Louisiana. J Autism Dev Disord 2008; 38(3): 481-8. doi: 10.1007/s10803-007-04140 .

57. Todd D, Todd H. Natural Disaster Response: Lessons from Evaluations of the World Bank and Others. Washington, DC: World Bank; 2011.

58. Australian Government, Department of Health. Australian Health Sector Emergency Response Plan for Novel Coronavirus (COVID-19). [cited 2020 Apr 22] Available from: https://www.health.gov.au/resources/publications/ australian-health-sector-emergency-response-plan-fornovel-coronavirus-covid-19.

59. Chinh DT, Bubeck P, Dung NV, Kreibich H. The 2011 flood event in the Mekong Delta: preparedness, response, damage and recovery of private households and small businesses. Disasters 2016; 40(4): 753-78. doi: 10.1111/disa.12171.

60. Government of the Republic of Trinidad and Tobago. National Flood Response Plan. Available from: http:// odpm.gov.tt/sites/default/files/Trinidad-Flood-Snapshot. pdf.

61. APP. National Disaster Response Plan 2019. Available from: https://app.adpc.net/resources/national-disaster-responseplan-2019-ndrp-2019/.

62. World Health Organization. Flooding: managing health risks in the WHO European Region (2017). [cited 2020 Nov 15] Available from: https://www.euro.who.int/en/ publications/abstracts/flooding-managing-health-risks-inthe-who-european-region-2017.

63. Govt. Philippines. Philippines: National Disaster Response Plan (As of June 2014). [cited 2020 Oct 20] Available from: https://reliefweb.int/report/philippines/philippinesnational-disaster-response-plan-june-2014.

64. Associated Programme on Flood Management. health and sanitation aspects of flood management. [cited 2021 Oct 12] Available from: https://www.floodmanagement. info/publications/tools/Tools_23_Health_and_Sanitation_ Aspects_of_Flood_Management.pdf.

65. Oktay F. The preparation and integration of Turkey's National Disaster Response Plan. [cited 2020 Oct 15] Available from: https://www.witpress.com/elibrary/wittransactions-on-the-built-environment/150/33921.

66. Korteweg HA, van Bokhoven I, Yzermans CJ, Grievink L. Rapid health and needs assessments after disasters: a systematic review. BMC Public Health 2010, 10(1), 1-12. doi.org/10.1186/1471-2458-10-295

67. United Nations Resident Coordinator'soffice in Mozambique. Mozambique Floods 2015. [cited 2020 Oct 17] Available from: https://reliefweb.int/sites/reliefweb. int/files/resources/Response\%20and\%20Recovery\%20 Proposal\%20to\%20Floods\%20in\%20Mozambique\%20 2015_Final.pdf.

68. Homeland Security. National Response Framework. [cited 2020 Nov 27] Available from: https://www.fema.gov/sites/ default/files/2020-04/NRF_FINALApproved_2011028.pdf.

69. Pan American Health Organization (PAHO). Institutional response to emergencies and disasters. [cited 2020 Jun 12] Available from: https://www.paho.org/disasters/ dmdocuments/Institutional_Response_to_Emergencies_ and_Disasters.pdf.

70. Rastegar MR, Ardalan A, Moradian MJ, Saberinia A, Nabavi M, Khankeh HR, et al. I.R.Iran National Health Disaster and Emergency Response Operations Plan (EOP). [cited 2020 Feb 11] Available from: http://home.sums. ac.ir/ moradij/wp/?p=3996.

71. Department of Homeland Security. National Response Plan. [cited 2020 Oct 25]: Available from: https://www.dhs. gov/xlibrary/assets/NRP_Brochure.pdf.

72. Hoang LP, Biesbroek R, Tri VPD, Kummu M, van Vliet MTH, Leemans $\mathrm{R}$, et al. Managing flood risks in the Mekong Delta: How to address emerging challenges under climate change and socioeconomic developments. Ambio 2018; 47(6): 635-49. doi: 10.1007/s13280-017-1009-4.

73. Kent County Council. Kent County Council Flood Response Plan. [cited 2020 Nov 17] Available from: https:// 
www.kent.gov.uk/__data/assets/pdf_file/0019/12097/ Flood-response-plan.pdf.

74. UN Office for the Coordination of Humanitarian Affairs. 2018 Somalia Flood Response Plan 15 May - 15 August 2018 (May 2018). [cited Nov 2020 18] Available from: https://reliefweb.int/report/somalia/2018-somalia-floodresponse-plan-15-may-15-august-2018-may-2018.

75. Pradhan EK, West Jr KP, Katz J, LeClerq SC, Khatry SK, Shrestha SR. Risk of flood-related mortality in Nepal. Disasters 2007; 31(1): 57-70. doi: 10.1111/j.14677717.2007.00340.x.

76. Zahran S, Brody SD, Peacock WG, Vedlitz A, Grover H. Social vulnerability and the natural and built environment: a model of flood casualties in Texas. Disasters 2008; 32(4): 537-60. doi: 10.1111/j.1467-7717.2008.01054.x.

77. Ahmad H, Bokhari JI, Siddiqui QT. Flashflood risk assessment in Pakistan. In 71st Annual Session Proceedings. [cited 2020 Oct 12] Available from: https://pecongress.org. pk/images/upload/books/FLASHFLOOD\%20RISK\%20 ASSESSMENT\%20IN\%20PAKISTAN\%20\%2828\%29.pdf.

78. Morrison A, Noble BF, Westbrook CJ. Flood risk management in canada's prairie provinces: an analysis of decision-maker priorities and policy preferences. Environ Manage 2019; 64(5): 608-25. doi: 10.1007/s00267-01901208-0.

79. Carter WN. Disaster Management: A Disaster Manager's Handbook. Philippines: Asian Development Bank; 2008.

80. Few R. Flood Hazards and Health: Responding to Present and Future Risks. London: Routledge; 2006. doi: 10.4324/9781849771351.

81. Pan American Health Organization. Natural Disasters: Protecting the Public's Health. Washington, D.C: PAHO; 2000.

82. Axelrod C, Killam PP, Gaston MH, Stinson N. Primary health care and the Midwest flood disaster. Public Health Rep 1994; 109(5): 601-5.

83. Watson JT, Gayer M, Connolly MA. Epidemics after natural disasters. Emerg Infect Dis 2007; 13(1): 1-5. doi: 10.3201/ eid1301.060779.

84. Malilay J, Flanders WD, Brogan D. A modified clustersampling method for post-disaster rapid assessment of needs. Bull World Health Organ 1996; 74(4): 399-405. 